\title{
Correction: The use of bluetooth low energy Beacon systems to estimate indirect personal exposure to household air pollution
}

\author{
Jiawen Liao - John P. McCracken - Ricardo Piedrahita - Lisa Thompson • Erick Mollinedo - Eduardo Canuz • \\ Oscar De Léon - Anaité Díaz-Artiga - Michael Johnson - Maggie Clark · Ajay Pillarisetti - Katherine Kearns • \\ Luke Naeher · Kyle Steenland · William Checkley · Jennifer Peel · Thomas F. Clasen · HAPIN investigators
}

Published online: 27 February 2020

(c) The Author(s) 2020. This article is published with open access

\section{Correction to: Journal of Exposure Science \& Environ- mental Epidemiology}

https://doi.org/10.1038/s41370-019-0172-z

In the original Article, Eric D. McCollum's name was incompletely stated (as Eric McCollum). This has been corrected in the HTML, PDF and XML versions of this article.
Open Access This article is licensed under a Creative Commons Attribution 4.0 International License, which permits use, sharing, adaptation, distribution and reproduction in any medium or format, as long as you give appropriate credit to the original author(s) and the source, provide a link to the Creative Commons license, and indicate if changes were made. The images or other third party material in this article are included in the article's Creative Commons license, unless indicated otherwise in a credit line to the material. If material is not included in the article's Creative Commons license and your intended use is not permitted by statutory regulation or exceeds the permitted use, you will need to obtain permission directly from the copyright holder. To view a copy of this license, visit http://creativecommons. org/licenses/by/4.0/. 